TEME, г. XLV, бр. 1, јануар - март 2021, стр. 367-382

\begin{tabular}{lr}
\hline \hline Прегледни рад & https://doi.org/10.22190/TEME200213020D \\
Примљено: 13. 2. 2020. & UDK 330.526.34
\end{tabular}

Ревидирана верзија: 6. 2. 2021.

Одобрено за штампу: 26. 2. 2021.

\title{
MACROECONOMIC ASPECTS OF PUBLIC-PRIVATE PARTNERSHIP
}

\author{
Aleksandar Đorđević ${ }^{*}$, Biljana Rakić² \\ ${ }^{1}$ Science and Technology Park Niš, Niš, Serbia \\ ${ }^{2}$ University of Niš, Faculty of Economics, Niš, Serbia
}

\begin{abstract}
Public-private partnership (PPP) has been getting momentum in market economies since the 1990s. Originally, it was created as a way of financing infrastructure projects, but its application since then has covered areas such as education, healthcare, high technology and many others. As the bulk of research in the domain of PPP is on the microeconomic impact and the analysis of the success of concrete PPP projects, the aim of this paper is to integrate these findings into a broader framework depicting macroeconomic aspects of public-private partnership. The existing literature, although not as extensive, points to several aspects that may affect economic development on the local, regional, and national levels, with greater adoption of PPP projects and their implementation. The paper introduces explanations for the elements of risk sharing between public and private partners, economic benefits, and costs in PPP, as well as the specific PPP channels of influence on the national economy and the PPP system dynamic model. One of the objectives is the analysis of the existing concept for estimating macroeconomic impacts of PPP, which could be used for evaluating its potential contribution to the growth and development of the national economy.
\end{abstract}

Key words: public-private partnership, risk in PPP, benefits of PPP, SD model.

\section{МАКРОЕКОНОМСКИ АСПЕКТИ ЈАВНО-ПРИВАТНОГ ПАРТНЕРСТВА}

Апстракт

Јавно-приватно партнерство (ЈПП) почело је интензивније да се примењује у привредама западних земаља од деведесетих година двадесетог века. Првобитно је креирано као начин финансирања инфраструктурних пројекта, међутим, његова примена сада обухвата и области попут образовања, здравства, високе технологије и многих других. Како већина истраживања из домена ЈПП говори о микроекономском утицају и анализи успеха конкретних пројеката ЈПП-а, * Аутор за кореспонденцију: Александар Ђорђевић, Научно-технолошки парк
Ниш, Александра Медведева бб, 18000 Ниш, Србија, aleksandar.djordjevic@ntp.rs 
намера аутора овог рада је интеграција тих налаза у шири оквир који приказује макроекономске аспекте јавно-приватног партнерства. Постојећа литература, иако не тако обимна, указује на неколико аспеката који могу утицати на економски развој на локалном, регионалном и националном нивоу, ширим усвајањем пројеката ЈПП и њиховом применом. У раду су представљени елементи поделе ризика између јавног и приватног партнера, економске користи и трошкови у ЈПП, као и посебни канали утицаја ЈПП на националну привреду и модел динамичног система ЈПП. Један од циљева је анализа постојећег концепта за процену макроекономског утицаја ЈПП, који би се могао користити за процену његовог могућег доприноса расту и развоју националне економије.

Кључне речи: јавно-приватно партнерство, ризик у ЈПП, користи од ЈПП, СД модел.

\section{INTRODUCTION}

A single definition of Public-Private Partnership (PPP) in its modern form cannot be stated (Engel, Fischer \& Galetovic, 2014). Some of the characteristics include longevity of partnership, participation of public and private entities, sharing risks between public and private partners, or/and creating a new company for undertaking a specific project. That new company is usually called a "special purpose vehicle" (Välilä, 2020, p.2). It is used for "financing, construction, operation and maintenance of infrastructure or other assets and delivering previously determined standard of services" (Välilä, 2020, p.2). There is no unanimity regarding the definition, but it is even more challenging to make proper analysis of PPP`s impacts on the macroeconomic level due to limited data, interconnections and causalities. Several studies about the macroeconomic impact of PPP lead to divergent conclusions. For example, in the most recent study with an econometric approach, Trujilo et $a l$. (2018) analysed successes and failures of PPP transport projects and discovered that the inclusion of private sector in transport projects positively affects income per capita. Some authors like Rhee and Lee (2007) found that investing in PPP does not lead to expected results, as the analysis in South Korea showed that investment in PPP does not indicate a significant relationship with economic growth. Also mentioned are the crowding out and crowding in effects, implying that the increase of investment in PPP associates with a decrease in public investment, and an increase in private investment. Other authors like Kim et al. (2011) found a generally positive impact of implementing PPP projects on national economic development. Traditional procurement is missing structural and functional features which make PPP more effective for infrastructure development. Partners divide the risk according to the capabilities in dealing with the specific risk type, attention is committed to details in providing and delivering products and services, new ways of gathering necessary funds are introduced and private organisational and managerial skills are being used. Although theoretical arguments are in favour of 
PPP and propose many economic benefits, empirical evidence remain very thin (Lee, Han, Gaspar \& Alano, 2018).

Partnership relies on the private sectors`s expertise, organizational models, technology and soft skills which appear necessary during the undertaking, particularly with limited fiscal resources (Iossa \& Martimort, 2015; European PPP Expertise Centre, 2015; de Bettignies \& Ross 2004). When signing a contract, the private entity commits itself to deliver a project timely, respect the target expenditures and maintain the assets according to the stipulated terms. Therefore, it is expected that PPP accomplishes a higher level of quality and performance than the traditional procurement (Davies \& Eustice, 2005). Some studies indicate that partnership guarantees good value for money because the selected PPP project is the best among other alternatives based on expected benefits compared with associated costs of a project. PPP model contains an incentive for the private partner in designing and building assets under lower price and reducing costs of maintenance until the contract ends and the asset is returned to the public sector (Davies \& Eustice, 2005; Henckel \& McKibbin, 2010; Iossa \& Martimort, 2015).

Change and development are inevitable in everything and so is the case with the public sector. New economic circumstances require an adequate response. The public sector needs to resemble to the private one more, and apply as many rules and principles from the private sector as possible. Public services ought to be tailored to the needs of end users. Decentralization, flexible structure with less hierarchy levels and more individual autonomy, as well as clear responsibility are more than needed in public management. The private sector's involvement could help to decrease the number of employees in public services, as overemployment is an inherent problem in the public sector. Supporters of new public management emphasize narrowing the gap between the public and private management (Rakić, 2011). As public sector can never become the same as the private one, an optimal mixture of the two is being made through the forms of public-private partnership. By dividing the responsibilities and risks between the public and private partners, the concept of PPP tries to solve some old and some new problems in public sector administration. In the following section, benefits and costs of PPP will be discussed. This paper mainly relies on secondary data analysis and the synthesis of previous results in order to review and analyse the macroeconomic aspects of publicprivate partnership. The lack of data especially for Serbia makes empirical tests difficult to perform at this point.

\section{RISK-SHARING, ECONOMIC BENEFITS AND COSTS OF PPP}

The question of risk allocation is one of the most important in every business endeavour and especially if there are several subjects who ought to share that risk. Long term and high value of the PPP projects are 
significantly contributing to the complexity in this regard. For example, infrastructure projects involve many risks, per se. If they are going to be realised through a public-private partnership, it is necessary that the arrangements of the risk allocation go towards the party that is more capable of dealing with them. The fulfilling of PPP contract obligations should be incentivized by adequately assigning risk among involved parties. If they are not adequately formulated, PPP contracts may generate high costs, not only private ones, but also social, as they would usually be covered, ultimately, by taxpayers. Making an analogy to big socialist companies which, once they encountered a loss and a fall in production and sales, never got back on track, some authors compare badly written infrastructure projects to white elephants (Engel, 2016; Henckel \& McKibbin, 2010). To avoid this, all aspects of PPP must be carefully considered, and maybe even more importantly, backed up by strong institutions. The strengthening of the institutions is not only valuable for PPP projects, but also for other venture capital undertakings and national economy in general. The longevity of infrastructure assets determines a limited number of choices for a government on how to procure them. Contracts with public and private entities are more complex due to exceptionally long execution time and the uncertainty about how it could affect both the project and the parties involved. Risk management and risk sharing analysis have to consider asset or service attributes, as well as expenditures during the project life cycle. If one divides the risks involved, exaggerating the cost of production would be one of the most important endogenous risk, usually borne and controlled by the private entity, while service or product demand represents an exogenous risk, which is usually borne by the public entity, although in most cases the demand cannot be adequately predicted. Academic circles give more attention to the former the mentioned risk, but the latter is also worth the attention. Engel et al. (Engel et al., 2013) analysed it, especially as it represents one of the key risks in transport projects, for example PPP for a highway or a tunnel. Optimal risk sharing contracts among partners should specify a contractible quality of service and not involve any moral hazard problems.

If PPP and traditional public procurement are compared, it is usually stated that the first one is more efficient although sometimes it produces higher expenditures. Value for money is the concept being used to make this comparison (UK HM Treasury, 2006; UK Department for Transport, 2015). More thorough research would include a detailed assessment of given choices and, in praxis, it usually comes down to the evaluation of their effect on the public budget. Buffie et al. (2016) compare the results if the investment is made through PPP or through public procurement. They conclude that PPP is associated with higher expenditures, but they also have better time management, complete projects on time and produce higher quality infrastructure. Also, they notice that PPP reduces "underinvestment in public cap- 
ital, underinvestment in infrastructure, unemployment and poverty", and find that "impact on macro externalities, specifically social return in PPP is 2-9 \% higher relative to own public investment" (Buffie et al., 2016. p. 26).

Micro and macroeconomic analyses of PPP have clear differences. The public partner's aim is securing the best possible arrangement by maximizing the incentives for delivering adequate assets while keeping the expenses as low as possible. In macro analysis the expenditures that the government endures are subtracted from the return of the PPP project. The result is compared to the net return calculated if public sector invested without making a partnership (Buffie et al., 2016). Some authors like Tirole (2009) suggested a framework to analyse pre-contractual transaction costs, but it was not applied to the specific problem.

Institutional, political, and fiscal context influence on the choice of the procurement method. To analyse the benefits and costs, the identification of the relevant groups of stakeholders on the market needs to be conducted. This means that the analysis should be extended beyond economic parameters (Leviakangas, 2019). As PPP is not solely an economic issue, politics surrounding PPP projects needs to be observed carefully and in depth as it plays an especially important role. Governments, particularly the ones with constrained budgets and restrictive fiscal policy, must find a way to invest in infrastructure and social services. Public-private partnership is one of the best means to attract private capital to participate in building public assets. This shows that PPP will become more and not less important in the future.

\section{THE CHANNELS OF PUBLIC-PRIVATE PARTNERSHIP IMPACT ON MACROECONOMIC PARAMETERS}

According to the Asian Development Bank (Arezki et al., 2016) PPP could mostly positively affect national development by influencing certain channels:

- Improved access to infrastructure

- Improved technical and institutional capacity, transparency and organizational skills

- Facilitated allocation of public resources

- Attracting private savings through long term investments Improved access to infrastructure is the first and most evident channel. Due to the transfer of operating risks, the private partner is more likely to increase the quality of infrastructure. The second channel points out the benefits from the improvement of the technical and institutional capacity, transparency, and organizational skills. All of these are brought to the public sector from the partnership with the private entities. Facilitated allocation of public resources by using PPP represents the third channel. This is explained as PPP are used for infrastructure services, public sector can invest more into 
education, health, and social security. Luring unused and uninvested private funds into long-run investments via PPP is addressed by the last channel. These funds include various mutual institutional funds, savings, as well as individual private savings. Directing these savings towards lucrative PPP projects optimizes income redistribution while contributing to national development (Arezki et al. 2016). According to Lee et al. (2018) some empirical evidence indicates significant macroeconomic contribution of PPP. It is said that social and pro-poor infrastructure play an essential role in reducing poverty through enhancing access to infrastructure and markets (Lee at al., 2018). For a PPP to be successful it requires certain preconditions to be fulfilled. Some of the most obvious ones are quality and well-defined institutions. Some authors like Hammami, Ruhashyankiko \& Yehoue (2006) associate a higher degree of PPP implementation with lower levels of corruption, as well as strict and rightful governance. Schomaker (2014) indicates the correlation between a higher degree of institutional quality and providing public services with the participation of private funds.

Different channels through which macroeconomic performance can be affected by PPP are presented in Figure 1. Infrastructure-growth link is made stronger if the partnership provides quality outcomes, does that timely and maintains the project adequately. Iossa and Martimort (2015) consider that packing various phases of providing infrastructure engaged with PPP leads private sector to more investment in the quality of goods compared to ordinary procurement. Advanced competencies that are necessary to be developed for complex PPP contracts will also be beneficial for reinforcing institutions. It can have multiple advantages as good technical capacity and good governance are beneficial in many public services. The second channel refers to the fact that infrastructure PPP allows the public sector to use more resources for services intended to develop human capital and social security. Lucrative PPP infrastructure projects could captivate income surpluses and assets from various investment funds and direct them towards important social projects. This could also affect income redistribution and attainment of not only economic, but also social goals. (Arezki et al. 2016).

There is also one specific link in Figure 1 which shows the 5P or "ProPoor Public-Private Partnership" (Lee et al., 2018, p. 6). Its goal is to develop a utility which will help poor societal groups via PPP. Providing energy through ecofriendly sources and making it available to the lowest income groups are some examples of these projects, carried out in underdeveloped countries (UNESCAP, 2014). "Developed countries have more projects that are in the category of social infrastructure and developing ones have more in the economic infrastructure part" (Djordjević \& Rakić, 2020, p.13). Building improved infrastructure, PPP contributes to economic growth which will in the long run affect the poor through stimulating employment and improving 


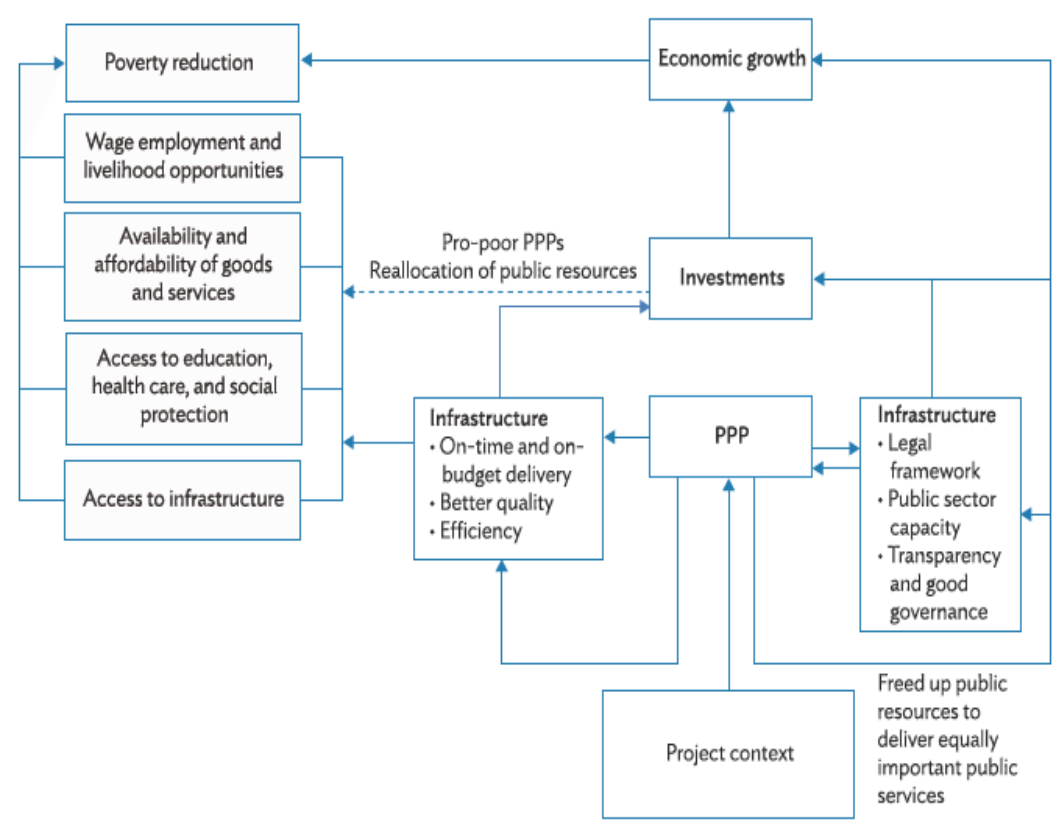

Figure 1. Public-private partnership channels of impact on national economy Source: Lee et al. (2018). p. 6

the quality of life. As low-income households spend more on basic goods and services, they ought to have access to the infrastructure they can afford. Wallich (2002) noted that the poor often cannot choose and are forced to use expensive alternatives for safe water and electricity. As it can be seen in Figure 1, most PPP impacts are transferred to macroeconomic parameters through infrastructure development, as economic development is very dependent on the quality level of the infrastructure. As a determinant in the analysis, PPP are involved as ratio between the value of PPP projects compared to the generated GDP. Public-private partnership investment boom leads to GDP growth. That can be seen on the following graph in Figure 2, from the authors Lee et al. (2018) where they state:

"The difference in economic growth reaches more than $2 \%$ but stabilizes 4 years later. Even so, this does not put the long-term growth impacts of PPPs in question, given the expected productivity improvements associated with better infrastructure". (Lee et al., 2018, p.9). 


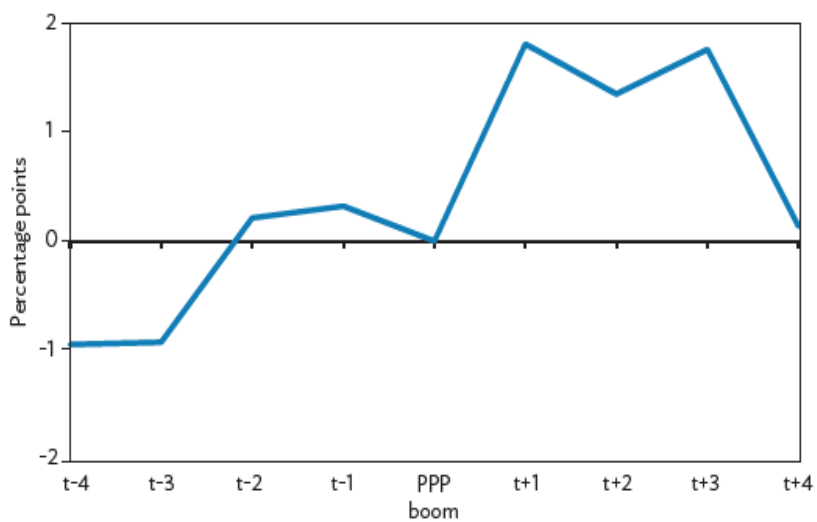

Figure 2. GDP increase prior to and after investing in PPP Source: Lee et al. (2018) p.10

Another conclusion from the aforementioned analysis states that the implementation of PPP contributes to public institutions' capacity to handle complex projects in other different areas. The realisation of a PPP project leads to the re-examining of regulations and policies and consequently the improvement of public management and capacity (Lee et al., 2018.).

It is indicated that PPP projects not only increase access to infrastructure but also, if the contracts are adequately made, enhance the quality of infrastructure services. Coefficients that were positive and significant in the tests are from energy sectors, telecommunications, water supply and sanitation. Access to telecommunications, specifically the number of mobile phones, showed one of the highest coefficients. This, however, also coincides with the general trend of increasing mobile phone subscriptions due to the private sector participation in this field (Prachitha, Mahalingam, Deep, \& Thillairajan, 2015).

Table 1. Effect of increasing PPP investment in ratio to GDP in Developing Asia

\begin{tabular}{|c|c|c|c|}
\hline Variable & $\begin{array}{l}\text { PPP ratio } \\
\text { increase } \\
\text { to } 1 \%\end{array}$ & $\begin{array}{c}\text { PPP ratio } \\
\text { increase } \\
\text { to } 2 \%\end{array}$ & $\begin{array}{c}\text { PPP ratio } \\
\text { increase } \\
\text { to } 3 \%\end{array}$ \\
\hline Increase in real per capita GDP growth (\%) & 0,1 & 0,3 & 0,4 \\
\hline $\begin{array}{l}\text { Reduction in the number of people without } \\
\text { electricity (mil.) }\end{array}$ & 14 & 41 & 69 \\
\hline $\begin{array}{l}\text { Reduction in the number of people without } \\
\text { proper sanitation (million) }\end{array}$ & 16 & 47 & 78 \\
\hline $\begin{array}{l}\text { Reduction in the number of people without } \\
\text { safe drinking water (million) }\end{array}$ & 12 & 36 & 60 \\
\hline
\end{tabular}

Source: Lee et al. (2018) p. 15 
Table 1 indicates the approximate results of increased investing in PPP as the ratio of GDP in developing Asia in some social categories and thus covering 5P which builds community-based utilities. This estimation was made based on the results from 2015 and the ratio of PPP to GDP of $0.5 \%$ (Lee et al., 2018). It shows that an increase of the percentage of PPP relative to GDP growth induces exponential growth of other social variables listed in the table and implicates a multiplier effect of investing in PPP.

Checherita (2009) indicates and analyzes 5 possible channels of PPP influence on some macroeconomic parameters:

1. Impact on aggregate private and public investment

2. Impact on government budget balance

3. Impact on government debt

4. Impact on fiscal risks

5. Impact on GDP growth rate" (Checherita, 2009, p. 86).

The first effect of PPP is raising private as well as public investment. This is usually noticed in the state budget in the position of private gross capital. This was proven on the sample of developing countries in South America: Argentina, Bolivia, Brazil, Chile, Colombia, Mexico and Peru. The connection with public investment is more complex and indicates a substitution effect. This means that more investments in PPP cause less investments in solely public assets in the coming years. Governments are trying to reduce the part of public infrastructure investing by directing their funds towards PPP. Nevertheless, this was not proven to be true on the whole sample of Latin America, although some countries like Argentina, Chile and Brazil have the most PPP programs with the highest value and the lowest ratio of public investment to GDP.

Maybe one of the most beneficial effects of PPP is its influence on the fiscal policy and national budget, more specifically on the public and publicly guaranteed debt. Not only that the government is not investing its own funds, and thus reducing the expenditure side, but also PPP projects are contributing to the revenue side of the budget. This connection is not necessarily proven in the developing countries due to many other expenditures, but certain evidence exists that engaging in large PPP projects has a positive impact on the fiscal stance. In general, this means reducing the government debt.

Empirical effect of PPP on fiscal risk is ambiguous. Partnership contributes to budget balance and the reduction of government debt, but large PPP projects could lead to higher fiscal risk. Reducing public investments as private ones are being used positively affects budget balance and government debt. If it happens that a project unfortunately fails and the contract is abandoned by the private partner, the public sector will be the one bearing the consequences, and citizens will have to pay indirectly through taxes.

As the most valuable macroeconomic variable is economic growth, most important goal for a government to launch PPP projects is to ensure that they can provide quality and constant services or goods. The period 
taken for the research is fifteen years (1990-2005), due to, especially, the longevity of the PPP contracts, and it is very hard to draw valuable conclusions about the correlation between PPP projects and economic growth. Bearing in mind that many other factors affect economic growth makes it even harder to isolate this specific connection (Checherita, 2009, pp. 84-125). Nevertheless, Checherita states:

"When I extend the sample period to 1980-2005 and use instead actual investment spending data from Calderon and Serven (2004), I find that private investment in infrastructure has had, on average, a positive impact on growth in the LA countries under analysis. This impact has mainly originated from private investment in roads a component undertaken mostly under PPP programs" (Checherita, 2009, p. 121).

There is a possibility to extend this survey and apply the given methodology on current data, using the same countries as the author, or transferring it to South-Eastern Europe where this kind of research has never been done. The lack of comparable data, especially for the Republic of Serbia is the biggest obstacle in conducting this kind of research. If the data would be provided, it would be the future plan of the authors to implement a similar kind of analysis.

\section{USING SYSTEM DYNAMICS MODEL TO EXPLAIN MACROECONOMIC IMPLICATIONS OF PPP}

All public-private partnerships share a lot of common things and although there are many specific aspects about a certain project, sector or a country, the system dynamics model is built on the assumption that PPP forms are essentially identical. Usually a private entity makes an agreement with the public one to design, build, finance and operate a property over a longer period, often over 20 years. The public entity pays for that regularly to the private one via pre-agreed installments during the contract period, under the condition that the provided services meet the required standards. These payments are called unitary charges. In certain circumstances as a delay in construction, non-operational facility or services below standard quality installments may be reduced accordingly. This model assumes that the only way to finance a project is through a PPP as this study evaluates projects' economic and social sustainability (Pagoni \& Patroklos 2019.).

As all public-private partnership projects together represent a relevant part of a national economy and affect creating jobs, capital forming and spread those effects further this SD model is created to interpret their growth (Parker, 2009). The public sector is concerned about the price as it needs to withstand future payments, whereas the private entity is willing to fund the project if it is profitable. From the point of view of capital market, 
financial institutions rely on the experience from previous successful PPP arrangements when deciding on financing further projects (Galilea \& Medda, 2010). The ability of the public sector to consistently repay instalments depends on the domestic market size, i.e. the number and financial capability of taxpayers (EIB, 2015).

If PPP is implemented in accordance with the development strategy and in sectors that provide a lot of jobs, it has a twofold effect. Unemployment is decreased and the labor market situation is improving, thus the number of taxpayers is increased. If it is not solved, among many other problems, unemployment leads to a decrease in the number of taxpayers and an increase of individual savings from precaution measures (Bentolila \& Ichino 2008).

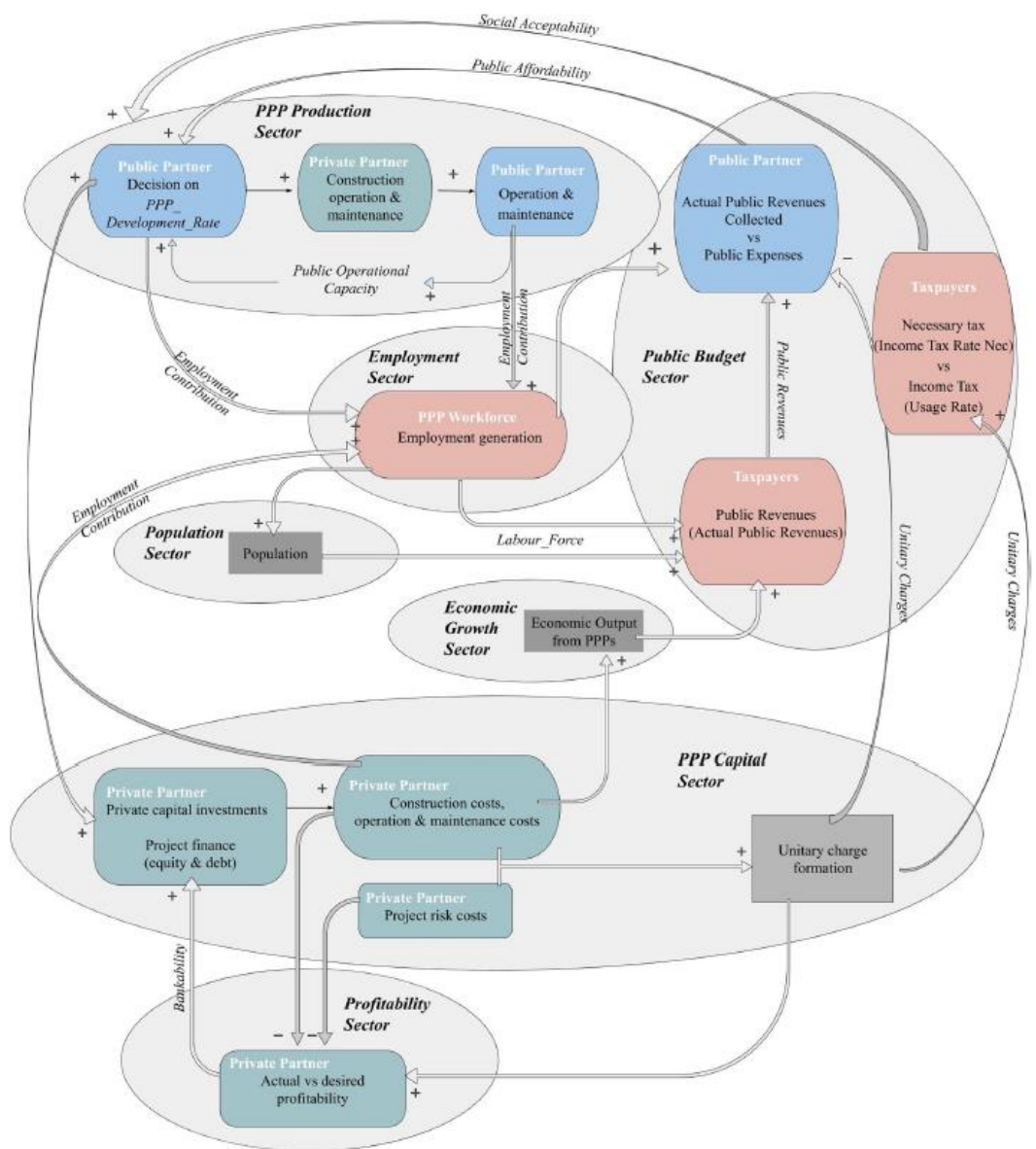

Figure 3. System dynamics model of PPP

Source: Pagoni \& Patroklos (2019). p. 5 
In Figure 3, links between different shareholders in PPP can be seen. There are public partners as public bodies, private partners in the form of investors and employees and taxpayers representing society. The system dynamics model is comprised of "seven sectors: PPP production, employment, PPP capital, profitability, economic growth, population, and public budget" (Pagoni \& Patroklos 2019, p.5). Until recently PPP literature was mainly focused on a case or type of projects, but this paper introduces a holistic approach of PPP successfulness and its sustainable development at the national level. The model shows how the system's internal structure and policies, the investors, the government and society, are related to national PPP programs. In addition to the private and public entities, the social dimension of PPP sustainable development has also been perceived.

\section{CONCLUSION}

This paper presents the macroeconomic aspects of public-private partnerships. PPP itself is not known or talked about enough so the introduction deals with the definition of the term and some of its basic determinants, as well as the macroeconomic aspects. The risks and its division in the formation and conclusion of PPP contracts between public and private entities were considered. The idea is that each entity bears the type of risk for which it has the most capability and that it is divided accordingly. The benefits as well as the costs of implementing and maintaining a PPP contract were then processed. The emphasis is, in addition to many microeconomic advantages (raising the quality of services, efficient management, the reduction of public sector costs), on macroeconomic benefits in the form of the reduction of public debt of the state, impact on employment, directing individual and group savings, fiscal budget, GDP growth rate. In terms of costs, one of the evident reductions is the pre-contractual activities and research that is necessary for the public sector to carry out. Then there are the annual fees that the public sector pays to the private sector if they are contracted. Afterwards the channels through which public-private partnerships exert a broader impact on the national economy are described. Four channels are mentioned: higher quality infrastructure; improved technical and institutional capacity, transparency, and organizational skills; facilitated allocation of public resources; the ability of PPP to attract private savings into longterm investments. Methodology used in the previous researches, as well as some empirical findings, is presented. The last segment uses the system dynamics model to present how the public-private partnership affects macroeconomic parameters. Socio-economic interactions among system actors are presented. There are public partners as public authorities, private partners in the form of investors and employees, and taxpayers representing the company. The system dynamics model is comprised of seven sectors: PPP production, employment, PPP capital, profitability, economic growth, population, and public budget. 
The successful implementation of public private partnership projects, considering that they contribute to infrastructure service quality, maintain and deliver projects on time, besides the fact that infrastructure has a strong bond with economic growth, indicates that consequently PPP could also be linked to economic growth. In the paper, some channels through which PPP can potentially contribute macroeconomic benefits have been presented. In order to carry out a PPP, the public sector needs to strengthen their institutional capacity as well as laws and regulations for PPP undertakings. Authorities also need to be transparent and well governed. Equally important are transparency and good governance. All these improvements could lead developing economies to invest more in other public services that target the poor as social protection or different subsidies. The private sector can engage in attaining the national development goal by using PPP. They have the potential to attract long-term savings and direct them towards long-horizon infrastructure projects. Adequately implemented public-private partnerships inevitably lead to an overall improvement and advancement not only for the local development and regions, but for the whole national economy.

Paper dominantly analysed the macroeconomic dimension of the public-private partnership. It presented channels of impact and the methodology for accessing PPP and using it to improve growth and development of national economies. Further research will be aimed towards analysing the situation of PPP in Serbia and in the region.

\section{REFERENCES}

Arezki, R. Bolton, P. Peters, S. Samama, F. \& Stiglitz, J. (2016). From Global Savings Glut to Financing Infrastructure: The Advent of Investment Platforms. IMF Working Paper, No. WP/16/18.

Bentolila, S. \& Ichino, A. (2008). Unemployment and consumption near and far away from the Mediterranean, Journal of Population Economics V 21(2):255-280, https://doi.org/10.1007/s00148-006-0081-z.

de Bettignies, J.-E. \& Ross, W.T. (2004). The Economics of Public-Private Partnerships. Canadian Public Policy, 30 (2): 135-54.

Buffie, E. Andreolli, M. Li, B.G. \& Zanna, L-F. (2016). Macroeconomic Dimensions of Public-Private Partnerships, IMF Working Paper, WP/16/78, International Monetary Fund.

Calderon, C. A. \& L. Serven (2004). Trends in Infrastructure in Latin America, 19802001. World Bank Policy Research Working Paper, No. 3401.

Checherita C. (2009). A Macroeconomic Analysis of Investment under Public-Private Partnerships and its Policy Implications - the Case of Developing Countries (PhD Dissertation), George Mason University Fairfax, VA. Retrieved from http://mars.gmu.edu/handle/1920/5658

Davies, P. \& Eustice, K. (2005). Delivering the PPP Promise: A Review of PPP issues and Activity. PricewaterhouseCoopers.

Djordjević, A. \& Rakić, B. (2020). Comparative analysis of PPP projects sectoral structure in developed and developing countries. FACTA UNIVERSITATIS Series: 
Economics and Organization, 17(2): 187-202, https://doi.org/10.22190/ FUEO200304014D

Engel, E. (2016). Public-Private Partnerships: Economic Theory and Public Policy. Presentation at the World Bank Development Economics Vice Presidency (DEC) Lecture Series, Washington DC.

Engel, E., Fischer, R., \& Galetovic, A. (2014). The Economics of Public-Private Partnerships: A Basic Guide. Cambridge: Cambridge University Press. doi:10.1017/CBO9781139565615

Engel, E. Fischer, R. \& Galetovic, A. (2013). The Basic Public Finance of Public-Private Partnerships, Journal of the European Economic Association, European Economic Association, 11(1): 83-111, https://ideas.repec.org/a/bla/jeurec/v11y2013i1p83111.html

European Investment Bank. (2015). A Web Version of the Guide to Guidance, Rebranded As 'The EPEC PPP Guide', European PPP Expertise Centre, Luxembourg, http://www.eib.org/epec/g2g/i-project-identification/12/121/index.htm

European PPP Expertise Centre. (2015). PPP Motivations and Challenges for the Public Sector: Why (Not) and How? http://www.eib.org/attachments/epec/epec_ppp_ motivations_and_challenges_en.pdf.

Galilea, P. \& Medda, F. (2010). Does the political and economic context influence the success of a transport project? An analysis of transport public-private partnerships, Research in Transportation Economics, 30(1): 102-109, https://doi.org/10.1016/ j.retrec.2010.10.011.

Hammami, M. Ruhashyankiko J.S. \& Etienne B. Yehoue. (2006). Determinants of Public-Private Partnerships in Infrastructure. IMF Working Paper, No. WP/06/99.

Henckel, T. \& McKibbin, W. (2010). The Economics of Infrastructure in a Globalized World: Issues, Lessons and Future Challenges. Brookings, Washington, DC.

Iossa, E. \& Martimort, D. (2015). The Simple Microeconomics of Public-Private Partnerships. Journal of Public Economic Theory, 17(1): 4-48.

Kim, J.-H. Kim, J. Shin, S. \& Lee, S.-Y. (2011). Public-Private Partnership Infrastructure Projects: Case Studies from the Republic of Korea: Volume 1: Institutional Arrangements and Performance. Manila: Asian Development Bank.

Lee, M. Han, X. Gaspar, R. \& Alano, E. (2018). Deriving Macroeconomic Benefits from Public-Private Partnerships in Developing Asia, No. 551, ADB Economics Working Paper Series, http://dx.doi.org/10.22617/WPS189465-2, Asian Development Bank.

Leviakangas, P. (2019). Public-private partnerships: integrating models of projects, business ecosystems and layered infrastructure markets. Annales universitatis turkuensis sarja - ser. E osa - tom. 44

Pagoni, E.G. Patroklos, G. (2019). A system dynamics model for the assessment of national public-private partnership programmes'sustainable performance, Simulation Modelling Practice and Theory, 97, 101949, https://doi.org/10.1016/ j.simpat.2019.101949.

Parker, D. (2009). EDITORIAL: PPP/PFI - SOLUTION OR PROBLEM?. Economic Affairs, 29: 2-6. doi:10.1111/j.1468-0270.2009.01859.x

Prachitha, J. Mahalingam, A. Deep, A. \& Thillairajan, A. (2015). Impact of Private Sector Participation on Access and Quality of Services: Systematic Review of Evidence from the Electricity, Telecommunications and Water Supply Sectors. Journal of Development Effectiveness, 7(1): 64-89.

Rakić, B. (2011). Javno privatno partnerstvo: prednosti i ograničenja [Public Private Partnership: Benefits and Limitations], Niš: Ekonomski fakultet. 
Rhee, C.-Y. \& Lee, H. (2007). Public-Private Partnerships in Infrastructure and Macroeconomy: The Experience of Korea. Performance Evaluation and Best Practice of Public-Private Partnerships. Sejong: Korea Development Institute.

Schomaker, R. (2014). Institutional quality and private sector participation: theory and empirical findings, European Journal of Government and Economics, Europa Grande, 3(2): 104-118. https://ideas.repec.org/a/egr/ejge00/v3i2p104-118.html

Tirole, J. (2009). Cognition and incomplete contracts. American Economic Review, 99 (1): 265-294.

UK Department for Transport. (2015). Value for Money Framework. London.

UK HM Treasury. (2006). Value for Money Assessment Guidance. November, London.

United Nations Economic and Social Commission for Asia and the Pacific (UNESCAP). (2014). 5P Approach: Partnerships for a Resilient Energy Future.

Välilä, T. (2020). An overview of economic theory and evidence of public-private partnerships in the procurement of (transport) infrastructure. Utilities Policy, 62(C), 100995, https://doi.org/10.1016/j.jup.2019.100995.

Wallich C. (2002). Soft Hearts and Hard Heads: The Private Sector's Centrality to Poverty Reduction. Defining an Agenda for Poverty Reduction: Proceedings of the First Asia and Pacific Forum on Poverty (Volume 1). Manila: ADB.

\title{
МАКРОЕКОНОМСКИ АСПЕКТИ ЈАВНО-ПРИВАТНОГ ПАРТНЕРСТВА
}

\author{
Александар Ђорђевић ${ }^{1}$, Биљана Ракић ${ }^{2}$ \\ ${ }^{1}$ Научно-технолошки парк Ниш, Ниш, Србија \\ ${ }^{2}$ Универзитет у Нишу, Економски факултет, Ниш, Србија
}

\section{Резиме}

У овом раду представљен је макроекономски аспект јавно-приватног партнерства. У уводу је дефинисан појам, неке његове основне одреднице, као и утицај на макроекономију. Сагледани су ризици и њихова подела приликом формирања и склапања уговора о ЈПП између јавних и приватних субјеката. Идеја је да сваки ентитет сноси онај тип ризика који има највише способности да контролише и умањи га, те да се на основу тога врши подела. Затим су обрађене користи и трошкови приликом примене и одржавања уговора о ЈПП. Акценат је, поред микроекономских предности, на макроекономским предностима у виду смањења јавног дуга државе, утицаја на запосленост, усмеравање индивидуалне и групне штедње, фискалну политику, стопу раста БДП-а. Што се тиче трошкова, један од очигледних јесу предуговорне активности и истраживања које је неопходно да спроведе јавни сектор. Након тога, ту су и годишње надокнаде које јавни партнер исплаћује приватном, уколико су оне уговорене. У наставку су описани канали путем којих јавно-приватна партнерства врше шири утицај на националну економију. Објашњавају се четири канала: боља и квалитетнија инфраструктура; побољшање техничких и институционалних капацитета, транспарентности и организационих вештина; олакшана алокација јавних ресурса; могућност ЈПП да привуку приватну штедњу у дугорочне инвестиције. Представљена је и методологија коришћена у претходним истраживањима, као и неки емпиријски резултати. Последњи сегмент користи модел динамичког система да покаже како јавно-приватно партнерство утиче на макроекономске параметре. Приказане су друштвено-економске интеракције међу актерима система. По- 
стоје јавни партнери као јавни органи, приватни партнери у облику инвеститора и запослених и порески обвезници, који представљају друштво. Модел динамике система састоји се од седам сектора: производња ЈПП-а, запосленост, капитал ЈПП-а, профитабилност, економски раст, становништво и јавни буџет.

Веза између инфраструктуре и економског раста постаје јача јер партнерски аранжмани утичу на квалитетније инфраструктурне услуге, боље одржавање и спровођење пројеката на време и у оквиру буџета. У раду су представљени неки канали преко којих ЈПП може да допринесе макроекономским параметрима у форми инфраструктурних пројеката или путем привлачења приватних инвестиција. За спровођење јавно-приватног партнерства неопходно је да јавни сектор ојача свој институционални капацитет, као и правни и регулаторни оквир. Једнако су важни и транспарентност и добро управљање. Сва ова побољшања могла би довести до тога да економије у развоју више улажу у друге јавне услуге које за кориснике имају сиромашне, нпр. социјална заштита или различите субвенције. Коришћењем ЈПП-а приватни сектор је у могућности да се укључи у постизање националних развојних циљева. Има потенцијал да привуче дугорочну штедњу и усмери је ка инфраструктурним пројектима дугог временског трајања. Адекватно спроведено јавно-приватно партнерство неминовно доводи до укупног побољшања и напретка, не само за локални развој и регионе већ и за целу националну економију.

Примарни циљ овог рада је да истакне макроекономску димензију јавно-приватног партнерства и детаљније представи канале утицаја, као и методологију за приступ ЈПП-у и његову употребу за побољшање раста и развоја националних економија. Даља истраживања биће усмерена на анализу стања ЈПП-а у Србији и у региону. 